\title{
TINGKAT KONSUMSI PROTEIN DI INDONESIA TAHUN 2014- 2017 DAN PENGARUHNYA TERHADAP RATA-RATA PENGELUARAN MASAYARAKAT DI DESA DAN DI KOTA
}

\author{
Siska Febriyanti S \\ Dosen Fakultas Ekonomi dan Bisnis Islam IAIN Batusangkar \\ e-mail: siskafebriyanti@iainbatusangkar.ac.idp
}

\begin{abstract}
This study aims to determine the development of the level of protein consumption in Indonesia from 2014-2017 and its effect on the expenditure of residents in the village and in the city. The method used in this study is a qualitative descriptive method with data that has been obtained based on secondary data from the Central Bureau of Statistics (BPS), namely data on average protein consumption according to people's food and average expenditure according to goods groups in Indonesia in 2014 to with 2017. The results of the study indicate that the level of protein consumption in Indonesia that the average protein consumption of this society in 2014 to 2017 is the highest in the consumption of grain commodities compared to other commodities. However, the percentage of grain consumption from 2014 to 2017 has decreased, because there have been many people consuming processed food. This is evidenced by the increase in consumption of finished food in that range of years. Then the expenditure level on vegetable protein commodities in the village is greater than in the city, while the expenditure on commodities of animal protein is greater in the city.
\end{abstract}

Key word: consumption, expenditure

\section{PENDAHULAN}

Setiap manusia memiliki yang tidak terpenuhi akan berdampak pada kelangsungan hidupnya. Namun, permasalahannya saat ini adalah dengan kebutuhan manusia yang selalu meningkat tidak didukung dengan alat pemuas kebutuhannya. Kebutuhan manusia ini juga berkaitan 
dengan kesehatan manusia itu sendiri, karena jika kebutuhannya tidak terpenuhi dengan baik, maka akan berdampak juga pada kesehatan manusia, seperti dalam memenuhi kebutuhan makan, dimana manusia juga harus didukung dengan mengkonsumsi makanan yang bergizi agar bisa lebih sehat.

Kenyataan saat ini bahwa Indonesia termasuk negara yang mengalami gizi buruk, terutama pada balita dan ibu hamil. Dimana saat ini berdasarkan sumber berita online (http://tirto.id) yang mendapatkan data bahwa Indonesia saat ini menempati urutan ke 101 dari 149 negara dalam indeks kesehatan global 2017. Ini kalah dari Malaysia, Thailand, Laos dan Vietnam yang sesame Negara ASEAN. Kenyataan ini juga didukung dengan data dari BPS tahun 2017, dimana persentasi balita yang kurus di Indonesia ada sebesar 59,10\%. Dari data tersebut berarti lebih dari setengahnya balita di Indonesia diindikasi memiliki gizi buruk atau tidak memiliki berat yang ideal. Selain itu, persentasi balita yang kekurangan protein sebesar $31,90 \%$, dibandingkan dengan persentasi yang sudah cukup protein sebesar $14,50 \%$. Ini berarti bahwa angka kecukupan protein (AKP) balita di Indonesia 94 | Jurnal Tamwil, Vol. V, No. 1, Januari-Juni 2019 masih rendah, sehingga balita di Indonesia masih banyak yang kekurangan protein.

Konsumsi ini tidak hanya konsumsi untuk pemenuhan kebutuhannya saja, tetapi juga untuk memenuhi keinginan setiap manusia. Ini tentu akan menyebabkan tingkat pengeluaran seseorang juga akan berbeda, karena dengan mengkonsumsi kita melakukan pengeluaran dari pendapatan yang diterima. Semakin banyak melakukan konsumsi, berarti semakin banyak pula pengeluaran yang dikeluarkan seseorang, begitu juga sebaliknya. Perilaku konsumsi seseorang dapat berdampak positif dan juga berdampak negatif bagi orang yang melakukannya.

Dampak positif dari perilaku konsumsi ini adalah dapat memenuhi kebutuhan seseorang. Jika kebutuhan seseorang sudah terpenuhi, maka akan mendatangkan kesejahteraan bagi ornag tersbut. Sedangkan perilaku konsumsi yang berlebihan dapat berdampak negatif bagi seseorang, karena konsumsi yang dilakukan bukan untuk memenuhi kebutuhannya, tetapi lebih untuk memenuhi keinginannya dan tingkat pengeluarannya pun juga akan meningkat. Ini sesuai dengan 
pendapat Rusdarti dan Kusmuriyanto (2008: 170), yang menyatakan bahwa konsumsi merupakan bagian pendapatan masyarakat yang digunakan untuk membeli barang dan jasa dalam rangka memenuhi kebutuhannya. Selain itu menurut Sukirno (2000: 337) yang menyatakan bahwa konsumsi merupakan perbelanjaan yang dilakukan oleh rumah tangga atas barang-barang akhir dan jasa-jasa dengan tujuan untuk memenuhi kebutuhan dari orang yang melakukan perbelanjaan tersebut.

Berdasarkan pengertian di atas, dapat disimpulkan bahwa konsumsi merupakan kegiatan memakai, menggunakan atau menikamati barang dan jasa dengan menggunakan pendapatan yang diperoleh guna untuk memenuhi kebutuhan hidup manusia. Jadi, konsumsi protein merupakan kegiatan memakai atau menggunakan segala bahan atau komoditi protein untuk memenuhi kebutuhan hidup manusia. Yang termasuk dalam komoditi protein adalah padi-padian, umbi-umbian, ikan, daging, telur, susu, sayursayuran, kacang-kacangan, buahbuahan, minyak dan lemak, bahan minuman, bumbu-bumbuan dan konsumsi protein lainnya.
Lebih lanjut Mardiyatmo (2010: 118) menjelaskan bahwa di dalam ilmu ekonomi, konsumsi berarti penggunaan barang dan jasa untuk memuaskan kebutuhan. Untuk melakukan kegiatan konsumsi diperlukan pendapatan, di mana besarnya pendapatan akan dapat mempengaruhi besarnya konsumsi, berarti besarnya konsumsi sama dengan besarnya jumlah pengeluaran. Sehingga dapat disimpulkan bahwa semakin tinggi tingkat konsumsi, maka semakin tinggi pula tingkat pengeluaranya.

Tingkat konsumsi seseorang dapat dipengaruhi oleh pendapatan seseorang, karena semakin tinggi pendapat seseorang, maka tingkat konsumsinya juga akan meningkat. Tingkat pendapatan ini akan berbeda pula dari pula dilihat dari wilayahnya, seperti di desa atau di kota. Sebagaimana menurut Rusdarti dan Kusmuriyanto (2008: 170), yang menyebutkan bahwa konsumsi dapat dipengaruhi oleh faktor berikut:

a. Pendapatan/tingkat kekayaan konsumen

b. Tingkat sosial ekonomi

c. Tingkat harga yang berlaku dan harga barang lain atau barang subtitusi

d. Selera konsumen 
e. Tingkat suku bunga yang berlaku

Secara matematika bisa dilihat fungsinya yaitu:

$\mathrm{C}=\mathrm{f}(\mathrm{Y}$, sosial ekonomi, $\mathrm{P}$, selera, suku bunga)

Konsumsi sama dengan pengeluaran, maksudnya jika kegiatan konsumsi dilakukan, berarti ada pengeluaran yang dilakukan dari pendapatan yang diperoleh. Menurut Mardiyatmo (2010: 120), ada dua jenis pengeluaran konsumsi, yaitu: pengeluaran konsumsi rumah tangga dan pengeluaran konsumsi pemerintah. Pengeluaran konsumsi rumah tangga berarti, pengeluaran yang dilakukan untuk memenuhi kebutuhan rumah tangga, seperti kebutuhan sehari-hari dalam rumah tangga, sedangkan pengeluaran konsumsi pemerintah merupakan pengeluaran yang dilakukan untuk memenuhi kebutuhan pemerintah, guna untuk kepentingan umum seperti untuk pembangunan jalan raya, dan sebagainya. Dari uraian tersebut, berarti konsumsi protein tergolong pada pengeluaran konsumsi rumah tangga, karena komoditi konsumsi merupakan kebutuhan pokok dalam kehidupan sehari-hari.

Menurut Keynes dalam Mardiyatmo (2010: 120) tingkat konsumsi minimal yang harus dipenuhi dan tidak tergantung kepada tingkat pendapatan. Artinya, walaupun tidak ada pendapatan, konsumsi harus tetap terpenuhi. Seperti komoditi protein yang merupakan kebutuhan pokok bagi manusia, walaupun pendapatan seseorang tidak tinggi, namun setiap orang akan tetap berusaha untuk mengkonsumsi protein untuk memenuhi kebutuhan hidupnya. Berdasarkan uraian penulis berkeinginan untuk menjelaskan bagaimana perkembangan konsumsi protein masyarakat Indonesia dan bagaimana pengaruhnya terhadap pengeluaran penduduk di desa dan di kota.

\section{METODE PENEUTAN}

Metode yang digunakan dalam penelitian ini adalah metode deskriptif kualitatif dengan data yang diperoleh berdasarkan data sekunder dari Badan Pusat Statistik (BPS). Data yang diambil adalah data rata-rata konsumsi protein menurut makanan masyarakat di Indonesia dan data persentase pengeluaran rata-rata perkapita menurut kelompok barang pada tahun 2014 sampai dengan 2017. Teknik pengumpulan data yang 
dilakukan adalah dengan melihat pangan, pertanian, kesehatan, dan perubahan data konsumsi dan sosial ekonomi secara terintegrasi. pengeluaran yang telah didapat dari Menurut Ariani (2007: 48) tahun 2014-2017 kemudian menyatakan bahwa perkembangan dideskripsikan dan diambil konsumsi protein di Indonesia dalam kesimpulan.

\section{HASIL PENEUTIANDANPEMBAHASAN}

Tingkat kecukupan konsumsi protein dapat digunakan sebagai indikator untuk melihat kondisi gizi masyarakat dan juga keberhasilan pemerintah dalam pembangunan era reformasi dan pasca krisis ekonomi, rata-rata konsumsi protein pada tahun 2005 adalah sebesar 55,2 gram/kapita/hari.

Berdasarkan data dari BPS diketahui rata-rata konsumsi protein dari tahun 2014-2017 yaitu sebagai berikut:

Rata-rata konsumsi protein $(\mathrm{kg}) / \mathrm{kapita}$ menurut kelompok makanan tahun 2014-2017

\begin{tabular}{|c|l|c|l|l|l|}
\hline No & \multicolumn{1}{|c|}{ Komoditi } & \multicolumn{1}{|c|}{ 2014 } & \multicolumn{1}{|c|}{2015} & \multicolumn{1}{|c|}{016} & \multicolumn{1}{c|}{2017} \\
\hline 1. & Padi-padian & 1,662 & 1,683 & 1,724 & 1,616 \\
\hline 2. & Umbi-umbian & 0,116 & 0,134 & 0,142 & 0,192 \\
\hline 3. & Ikan & 0,703 & 0,607 & 0,603 & 0,734 \\
\hline 4. & Daging & 0,091 & 0,111 & 0,119 & 0,133 \\
\hline & JUMLAH & $\mathbf{4 , 5 8 6}$ & $\mathbf{4 , 5 5 0}$ & $\mathbf{4 , 6 0 4}$ & $\mathbf{4 , 6 9 2}$ \\
\hline
\end{tabular}

\section{Sumber: www.bps.go.id}

Dari tabel di atas dapat terlihat bahwa rata-rata konsumsi protein dari tahun 2014 sampai tahun 2017 mengalami peningkatan yaitu dari 4,586 kg menjadi 4,692 kg. Rata-rata konsumsi protein per kapita menurut kelompok makanan dari tahun 20142017 yang paling tinggi tingkat Selain itu, hasil ini juga didukung konsumsinya adalah pada kelompok dengan hasil penelitian yang makanan padi-padian dibandingkan kelompok makanan yang lainnya. Hal ini sesuai dengan penelitian yang dilakukan Setiawan (2006: 69), yang menemukan bahwa sebagian besar protein didominasi oleh protein nabati, yaitu padi-padian (beras). 
dilakukan oleh Chalid (2010: 37), yang menemukan bahwa kelompok makanan yang dikonsumsi paling besar adalah kelompok makanan padipadian.

Walaupun padi-padian setiap tahun tingkat konsumsinya paling tinggi, tetapi rata-rata konsumsi padipadian dari tahun 2014-2017 mengalami penurunan sekitar 0,69\%, yaitu dari rata-rata konsumsi 1,662 kg pada tahun 2014 turun menjadi 1,616 kg pada tahun 2017. Hal ini terjadi kemungkinan karena masyarakat telah banyak mengkonsumsi makanan jadi. Ini dibuktikan dengan terjadinya peningkatan rata-rata pengeluaran pada makanan jadi dari tahun 2014 sampai dengan tahun 2017, yaitu dari rata-rata Rp 103.762 meningkat menjadi Rp 172.600 dengan tingkat kenaikan pengeluaran sebesar $\mathrm{Rp}$ 68.838 Sedangkan rata-rata konsumsi protein yang terendah dari tahun 2014 sampai dengan tahun 2017 terjadi pada kelompok makanan daging. Berdasarkan data di atas dapat disimpulkan juga bahwa diantara rata-rata konsumsi protein nabati padi-padian dengan umbi-umbian, lebih banyak masyarakat yang mengkonsumsi padi-padian, sedangkan pada protein hewani, masyarakat Indonesia lebih banyak yang mengkonsumsi ikan dibandingkan daging. Hasil tersebut bisa dilihat dalam bentuk grafik berikut:

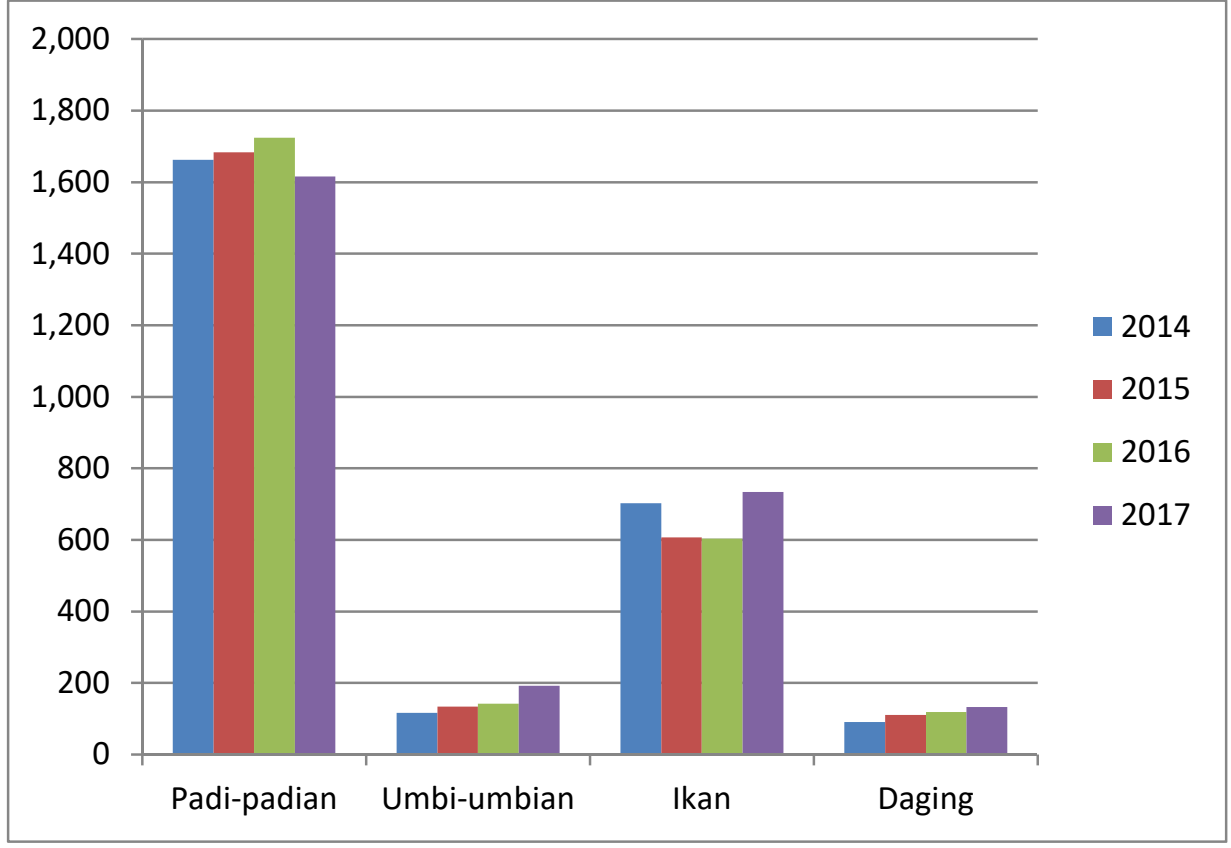

Gambar 1. Grafik Rata-rata Konsumsi Per Kapita tahun 2014-2017

98 | Jurnal Tamwil, Vol. V, No. 1, Januari-Juni 2019 
Berdasarkan gambar di atas dapat dilihat bahwa komoditi padi-padian lebih dominan dikonsumsi masyarakat dan diiringi dengan komoditi ikan sebagai protein hewani yang dikonsumsi masyarakat untuk memenuhi kebutuhan pokoknya sehari-hari.

Tingkat konsumsi protein di Indonesia dipengaruhi oleh tingkat pendapatan masyarakat, yang dikaitkan dengan tingkat pengeluaran rata-rata masyarakat Indonesia untuk mengkonsumsi komoditi protein. Dengan meningkatnya pendapatan seseorang, maka ini akan mempengaruhi konsumsinya, sebagaimana menurut Keynes dalam Chalid (2010: 31) yang menyatakan bahwa salah satu fungsi konsumsi adalah apabila pendapatan meningkat, maka tingkat konsumsi juga akan meningkat, namun apabila suatu keluarga tidak mempunyai pendapatan sekalipun, mereka masih tetap melakukan konsumsi. Hal ini disebabkan karena konsumsi merupakan kebutuhan setiap manusia. Selain itu, menurut James $\mathrm{S}$ Duesenberry (1949) dalam Chalid (2010: 32) mengemukakan teori konsumsi yang disebut Relative Income Hypothesis yang menyatakan bahwa pengeluaran konsumsi dari individu atau rumah tangga tidak bergantung pada pendapatan sekarang akan tetapi lebih bergantung pada tingkat pendapatan tertinggi yang pernah dicapai seseorang sebelumnya. Jadi, dapat disimpulkan bahwa pengeluaran konsumsi seseorang itu tidak tergantung pada pendapatannya pada saat ini, tetapi tergantung pada pendapatan tertinggi yang pernah dicapainya. Untuk lebih jelasnya, berikut ini disajikan data persentase pengeluaran rata-rata masyarakat di Indonesia: 
Persentase pengeluaran rata-rata perkapita sebulan menurut kelompok barang (Rupiah) di Indonesia tahun 2014-2017

\begin{tabular}{|c|c|c|c|c|c|c|c|c|c|}
\hline \multirow{2}{*}{ No } & \multirow{2}{*}{ Kelompok barang } & \multicolumn{2}{|c|}{2014} & \multicolumn{2}{|c|}{2015} & \multicolumn{2}{|c|}{2016} & \multicolumn{2}{|c|}{2017} \\
\hline & & Kota & Desa & Kota & Desa & Kota & Desa & Kota & Desa \\
\hline 1. & Padi-padian & 54117 & 88376 & 58740 & 72260 & 58122 & 71390 & 54853 & 68895 \\
\hline 2. & Umbi-umbian & 2566 & 4570 & 3816 & 5135 & 4486 & 5663 & 5012 & 6611 \\
\hline 3. & Ikan & 33385 & 30307 & 33358 & 30701 & 35799 & 31313 & 43206 & 37402 \\
\hline 4. & Daging & 19361 & 10583 & 23563 & 12437 & 26902 & 13774 & 31054 & 18150 \\
\hline
\end{tabular}

Sumber: www.bps.go.id

Berdasarkan data di atas, maka dapat dilihat bahwa pengeluaran terbesar masyarakat di desa lebih besar pada komoditi protein nabati, sedangkan di kota pengeluaran terbesar pada komoditi protein hewani. Persentase terbesar pengeluaran rata-rata perkapita sebulan pada komoditi protein nabati ada pada kelompok barang padipadian sedangkan pada komoditi protein hewani ada pada kelompok barang makanan ikan. Hal ini disebabkan karena masyarakat Indonesia pada umumnya mengkonsumsi padi-padian terutama beras untuk makanan pokoknya, sedangkan untuk protein hewani masyarakat memang cenderung memilih ikan, karena dari segi harga ikan lebih murah dibandingkan daging.

100 | Jurnal Tamwil, Vol. V, No. 1, Januari-Juni 2019
Sesuai dengan teori sebelumnya menyebutkan bahwa salah satu faktor yang mempengaruhi konsumsi masyarakat adalah tingkat sosial ekonomi masyarakat, yaitu seperti lokasi tempat tinggal masyarakat. Di mana, sesuai dengan data di atas bahwa terdapat perbedaan antara pengeluaran masayarakat di desa dengan di kota, ini tentunya disebabkan karena pendapatan yang berbeda juga, serta kebutuhan yang berbeda juga. Berdasarkan data di atas, dilihat dari kelompok barang protein nabati jumlah pengeluaran yang besar dari tahun 2014-2017 yang paling besar terlihat pada masyarakat yang tinggal di desa, sedangkan untuk kelompok protein hewani lebih besar pada masyarakat yang tinggal di kota. Hal ini sesuai dengan temuan Ariani (2007: 48), yaitu apabila dipilah menurut wilayah, konsumsi protein di 
kota menurun, sedangkan di pedesaan menunjukkan peningkatan. Fenomena ini diduga bukan karena faktor pendapatan, karena pendapatan rumah tangga yang diproksi dengan pengeluarannya di kota, lebih besar dari pada rumah tangga di desa, yaitu Rp 319.220/kapita/bulan di kota dan Rp 171.435/kapita/bulan di desa pada tahun 2004. Selain itu, perbedaan pengeluaran dilihat dari wilayah tempat tinggal juga ditemukan pada penelitian Chalid (2010: 37) yang menjelaskan bahwa pengeluaran konsumsi di kota lebih besar dari pada di desa. Tingginya tingkat pengeluaran di kota ini tidak hanya disebabkan untuk mengkonsumsi makanan yang akan diolah kembali, tetapi lebih banyak untuk mengkonsumsi makanan jadi.

\section{PENUTUP}

Berdasarkan pembahasan di atas, maka dapat disimpulkan bahwa ratarata konsumsi protein masyarakat pada tahun 2014 sampai dengan tahun 2017 di Indonesia yang tertinggi adalah konsumsi komoditi padipadian. Akan tetapi, persentase konsumsi padi-padian dari tahun 2014 sampai dengan tahun 2017 mengalami penurunan, karena telah banyaknya masyarakat mengkonsumsi makanan jadi. Ini dibuktikan dengan peningkatan konsumsi makanan jadi pada rentangan tahun tersebut.

Jumlah komsumsi yang dilakukan masyarakat berpengaruh pada jumlah pengeluarannya, dimana jumlah konsumsi terhadap padi-padian lebih tinggi dari umbi-umbian, ikan dan daging, maka pengeluaran juga tinggi pada komoditi tersebut. Kemudian dengan melihat perbandingan konsumsi dan pengeluaran di desa dan di kota, pengeluaran terbesar di desa terdapat pada konsumsi makanan komoditi protein nabati, sedangkan di kota pengeluaran terbesar ada pada konsumsi komoditi protein hewani.

\section{KEPUSTAKAANACUAN}

Ariani, Mewa. 2007. "Konsumsi Pangan Masyarakat Indonesia Analisis Data Susenas 19992005". (online): http://www.scribd.com, diakses tanggal 10 Oktober 2018.

Badan Pusat Statistik. Persentase Angka Kecukupan Protein (AKP) Balita di Indonesia tahun 2017. http://www.bps.go.id.

Badan Pusat Statistik. Rata-Rata Konsumsi Per Kapita Seminggu Beberapa Macam Bahan 
Makanan Penting 2007-2017. Mardiyatmo. 2010. Ekonomi 1 SMA http://www.bps.go.id. kelas $X$. Jakarta: Yudistira.

Badan Pusat Statistik. Rata-rata Rusdarti dan Kusmuriyanto. 2008. Pengeluaran Per Kapita Sebulan Ekonomi Fenomena di Sekitar Menurut Kelompok Barang Kita. Jakarta: Platinum. tahun 2013-2017. http://www.bps.go.id.

Chalid, Nursiah. 2010. Pengeluaran Konsumsi Rumah Tangga di Daerah Riau. Jurnal Ekonomi. Volume 18. Nomor 1. Hal 28-40.

Debora, Yantina. (Berita on line http://tirto.id. 17.Desember Sukirno, Sadono. 200o. Makro 2017), diakses 10 Oktober 2018.

Setiawan, Nugraha. 2006. Perkembangan Konsumsi Protein Hewani di Indonesia: Analisis Hasil Suvey Sosial Ekonomi Nasional 2002-2005. Jurnal Ilmu Ternak. Volume 6 Nomor 1. Hal. 68-74.

Ekonomi Modern. Jakarta: PT. Raja Grafindo Persada. 